\title{
Pengaruh Kelembagaan, Pembiayaan, dan Kemandirian terhadap Kewirausahaan Petani Padi metode Hazton di Kabupaten Menpawah Kalimantan Barat
}

\author{
Ridha Rizki Novanda \\ Fakultas Pertanian, Universitas Bengkulu, Bengkulu, Indonesia \\ Email korespondensi: rrizkin@unib.ac.id
}

\begin{abstract}
Menpawah Regency is the center of potential Hazton rice cultivation to be developed. The entrepreneurial spirit of farmers is essential in its development. It is important to analyze the influence of institutional, financing, and independence on the entrepreneurship of rice farmers. The study was conducted on rice farmers using the Hazton system. Purposive sampling locations in the area of rice production centers in the Hazton system. Data analysis was performed with descriptive analysis and ordinal regression. The results showed that institutional, financing, and independence had a significant effect on entrepreneurship.
\end{abstract}

Keywords: Ordinal, Institutional, Entrepreneurship, Financing. Independence

\section{INTISARI}

Kabupaten Menpawah merupakan sentral budidaya padi sistem Hazton yang potensial untuk dikembangkan. Jiwa kewirausahaan petani sangat pending dalam pengembangannya. Penting dilakukan analisis pengaruh kelembagaan, pembiayaan dan kemandirian terhadap kewirausahaan petani padi. Penelitian dilakukan pada petani padi yang menggunakan sistem Hazton. Lokasi pengambilan sampel secara purposive di daerah sentra produksi padi sistem Hazton. Analisis data dilakukan dengan analisisi deskriptif dan regresi ordinal. Hasil penelitian menunjukkan bahwa kelembagaan, pembiayaan dan kemandirian berpengaruh signifikan terhadap kewirausahaan.

Kata kunci: Ordinal, Kelembagaan, Kewirausahaan, Pembayaan. Kemandirian

\section{PENDAHULUAN}

Padi merupakan makanan pokok bagi masyarakat Indonesia, komoditas padi menjadi komoditas strategis yang selalu diperhitungkan keberadaannya di dalam negeri. Padi menjadi sangat sensitif apabila keberadaanya tidak dapat memenuhi pangan dalam negeri sehingga beberapa tahun terakhir Indonesia harus melakukan impor beras dari negara lain guna untuk memenuhi kecukupan konsumsi beras di Indonesia.Kondisi tersebut menunjukkan bahwa komoditas ini benar-benar komoditas pangan paling peting keberadaannya di Indonesia.

Komoditas padi merupakan komoditas strategis di Provinsi Kalimantan Barat. Luas panen padi di Kalimantan Barat merupakan luas panen paling besar di seluruh Kalimantan. Luas panen padi di Kalimantan Barat pada tahun 2015 mencapai 433.944 ha dengan produktivitas sebesar $29.40 \mathrm{kuintal} / \mathrm{ha}$. Sebagian besar lahan tersebut berupa lahan tadah hujan dengan musim tanam 1-2 kali per tahun. Pertumbuhan kebutuhan beras yang semakin meningkat setiap tahunnya di pulau kalimantan sangat menentukan tingginya kebutuhan beras di Kalimantan. 
ISSN : 2622-6154 (print)

Lumbung padi di Kalimantan Barat salah satunya yaitu Kabupaten Menpawah, yang menjadi prioritas pemerintah untuk meningkatkan produktivitas padi Teknologi budidaya Hazton merupakan rekayasa budidaya padi yang ditemukan oleh Ir. Hazairin, MS dan Anton Komarudin, SP, MSi. Teknologi Hazton bertumpu pada penggunaan bibit tua 25-30 hari setelah semai dengan jumlah bibit 20-30 batang per lubang tanam (Abdulrachman et al, 2015).

Menurut Noviansyah dan Bariyah (2018), Teknologi Budidaya menggunakan metode Hazton merupakan teknologi Budidaya yang menguntungkan di Kalimantan Barat. Hal tersebut dibuktikan dengan nilai $\mathrm{R} / \mathrm{C}$ rasio yang mencapai angka 2,69. Kondisi tersebut menunjukkan bahwa metode bubidaya Hazton ini sangat menguntungkan bagi masyarakat petani di Kalimantan Barat. Kondisi tersebut juga menunjukkan bahwa metode Hazton merupakan teknik budidaya yang layak untuk diusahakan mengingat penambahan produktivitas per hektar yang dihasilkan.

Kelayakan suatu usaha sangat berpengaruh terhadap keberlangsungan usahatani budidaya padi metode Hazton. Metode Hazton dipercaya dapat meningkatkan produktivitas 1-4 kali dari produktivitas sebelumnya. Hal ini sesuai dengan Sasaran utama pembangunan pertanian yaitu peningkatakan pendapatan petani (Ningrum \& Effendy, 2008). Metode ini sudah banyak diadopsi oleh petani pada Provinsi Kalimatan Barat dan didukung perkembangannya oleh pemerintah daerah maupun Bank Indonesia. Saat ini Provinsi Kalimantan Barat menjadi sentral budidaya Hazton di Indonesia.

Tingginya nilai kelayakan usahatani budidaya padi menggunakan metode Hazton pada Provinsi Kalimantan Barat khususnya Kabupaten Menpawah menunjukkan bahwa usahatani ini sangat potensial untuk dikembangkan. jiwa kewirausahaan petani sangat diperlukan dalam pengembangan budidaya padi menggunakan metode Haston. Jiwa keirausahaan sangat penting ada pada petani sehingga mendapatperhatian serius dari pemerintahyang mendorong munculnya wirausaha baru dengan Gerakan Kewirausahaan Nasional (Darmaji, 2012). Kewirausahaan penting dan sangat menentukan keberhasilan suatu usaha yang berorientasi pasar (Wibowo \& Subiyono, 2005). Sehingga kewirausahaan sangat penting utuk dianalisis pada budidaya padi metode Hazton.

Kelembagaan di desa tidak lepas dari usahatani. Konsep Kelembagaan usahatani sudah sangat melekat untuk memperkuat usahatani. Upaya meningkatkan efisiensi dan efektivitas kewirausahan diawali melalui pembenahan kelembagaan petani. Pada Kabupaten Menpawah terdapat Gabungan Kelompok Tani (Gapoktan) Nekat Maju yang telah berdiri sejak tahun 2012,yakni Kelompok tani dengan jumlah anggota pengadopsi Hazton terbanyak di Kabupaten Menpawah. Gapoktan tersebut merupakan gabungan dari 11 kelompok tani yang tersebar di Desa Paniraman dengan jumlah petani dan jumlah lahan masing-masing sebesar 275 orang dan kurang lebih sebesar 275 ha lahan sawah tadah hujan. Gapoktan ini dipilih karena memiliki modal sosial yang kuat disertai semangat untuk menerapkan inovasi baru.

Selain konsep kelembagaan, Pembiayaan pertanian juga sangat menentukan bangaimana keberlangsungan usahatani padi Hazton didesa tersebut. =Keberadaannya dapat meningkatkan tingkat kewirausahaan petani. Menurut Rahmawati et al (2015), akses terhadap lembaga pembiayaan pertanian berpengaruh terhadap motivasi kewirsausahaan petani padi. kajian akses pembiayaan sangat penting bagi peningkatan jiwa kewirausahaan petani.

Kemandirian menjadi salah satu penentu kewirausahaan bagi petani. Konsep kemandirian merupakan karakter dari seorang wirausaha. Kemandirian tidak lepas dari suatu sikap yang tidak ingin bergantung dengan orang lain. seorang wirausaha harus 
bersikap mandiri dalam menjalankan usahataninya. Oleh karena itu penting untuk dianalisis bagaimana pengaruh kelembagaan, pembiayaan dan kemandirian terhadap kewirausahaan petani padi.

\section{METODE PENELITIAN}

Penelitian dilakukan pada petani padi Hazton yang mengelola dan menggarap lahannya sendiri (bukan buruh tani) di Desa Paniraman, Kabupaten Menpawah, Provinsi Kalimantan Barat. Lokasi penelitian dipilih secara purposive dikarenakan daerah tersebut merupakan sentra produksi padi metode Hazton di kabupaten Menpawai. Data yang digunakan ialah data primer. Data primer merupakan data lapangan yang diperoleh secara langsung yaitu data dari hasil wawancara dan kuesioner.

Analisis data dilakukan meliputi:

1. Analisisis deskriptif

Analisis deskriptif membahas karakteristik responden petani padi metode Hazton. Selanjtnya membahas mengenai sebaran jawaban kelembagaan, pembiayaan, dan kemandirian terhadap kewirausaan petanipadi metode Hazton

2. Analisis Pengaruh Kelembagaan, Pembiayaan, dan Kemandirian terhadap Kewirausahaan Petani Padi metode Haston di Kabupaten Menpawah Kalimantan Barat

Analisis pengaruh dilakukan dengan analisisi regresi ordinal yang digunakan untuk menganalisasi variabel respon dengan variabel prediktor. Variabel respon bersifat polikotomus dengan skala ordinal. metode ini sangat sesuai digunakan untuk penelitian dengan variabel respon berskala ordinal seperti penelitian ini. Tahapan regresi ordinal meliputi tahapan berikut (Ryan, 1997).

a. Model Fitting Information (Uji Keberartian Model)

Pada tahap ini menjelaskan mengenai masuknya variabel independen ke model final. Hal tersebut menyebabkan naik/turunnya nilai final model. Kondisi tersebut menghasilkan Chi-Square yang signifikan lebih kurang dari nilainya atau model yang layak digunakan.

b. Goodness of Fit (Uji Kebaikan Model)

Goodness of Fit menunjukkan uji kesesuaian model dengan data dimana signifikan harus lebih besar dari nilai alfa. Hal tersebut menunjukkan model sesuai dengan data empiris atau model layak untuk digunakan kembali. Pada tahap ini dilakukan dengan uji deviance. Rumus statistik deviance sebagai berikut: 


$$
D=-2 \sum_{i=1}^{n}\left[y_{i} \ln \left(\frac{\hat{\pi}_{i}}{y_{i}}\right)+\left(1-y_{i}\right) \ln \left(\frac{1-\hat{\pi}_{i}}{1-y_{i}}\right)\right]
$$

dengan

$$
\begin{gathered}
\hat{\pi}_{i}=\frac{\exp \left(g\left(x_{i}\right)\right)}{1+\left(g\left(x_{i}\right)\right)} \\
g\left(x_{1}\right)=\beta_{0}+\beta_{1} x_{n}+\cdots+\beta_{p} x_{i p}, i=1,2, \ldots, n
\end{gathered}
$$

c. Koefisien Determinasi Model

Koefisien determinasi menunjukkan bahwa seberapa besar variabel bebas mampu menjelaskan variabel dependen. Nilai ini seperti halnya koefisien determinasi pada regresi

d. Hasil Uji Hipotesis Parsial

Uji hipotesa partial digunakan untuk melihat hasil pengujian hipotesis dari masing-masing variabel. Uji parsial lebih cenderung digunakan untuk melihat pengaruhmasing-masing variabel independent terhadap variabel dependent dan tindak lanjut kepada odds ratio

$$
Z^{2}=\left(\frac{\hat{\beta}_{k i}}{S E\left(\hat{\beta}_{k i}\right)}\right)^{2}
$$

\section{HASIL DAN PEMBAHASAN}

\section{Karakteristik Responden}

Umur menjadi salah satu aspek penting dalam melakukan usahatani. kemampuan menyerap teknologi dan adopsi inovasi sangat berhubungan dengan umur dari petani. Semakin muda umur petani, maka akan semakin mudah petani untuk menyerap teknologi inovasi pertanian (Wangke \&Suzana, 2016). Berdasarkan hasil penelitian pada gambar 1, didapatkan bahwa umur responden mayoritas di usia 21 tahun hingga 38 tahun sebanyak $44 \%$. Sedangkan minoritas umur 55 tahun keatas dengan persentase 13\%. Kondisi tersebut menunjukkan bahwa kemampuan petani menyerap teknologi budidaya baru Hazton lebih mudah dikarenakan dominasi petani yang memiliki usia muda. 


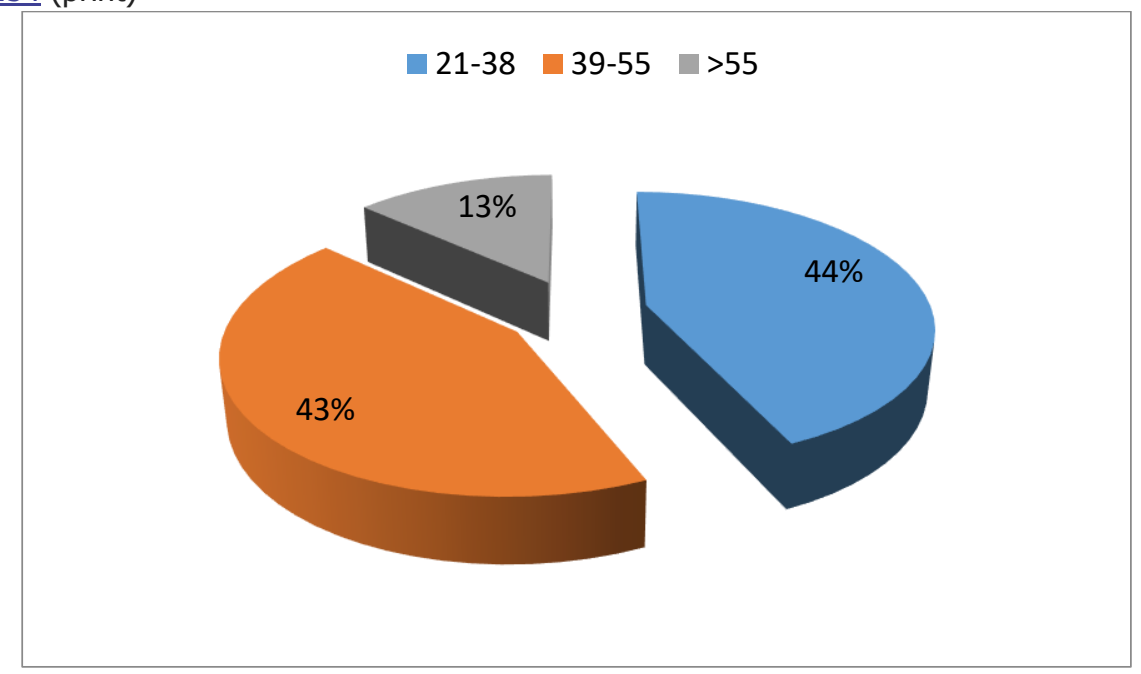

\section{Gambar 1 Umur Petani}

Responden yang mengusahakan budidaya padi Hazton ini seimbang antara lakilaki dan perempuan yaitu $50 \%$ dan $50 \%$. Tingginya persentase perempuan mengusahakan adi Hazton dikarenaan suami yang bekerja disektor lain. Sehingga istri harus memenuhi kebutuhan keluarga dengan mengusahakan padi Hazton. Tak berbeda dengan laki-laki, wanita juga sangat berperan dalam penyerapan teknologi inovasi. Endang et al. (2014) menyatakan bahwa wanita tani cukup berperan dalam penerapan teknologi pertanian, faktor yang mendorong perempuan berperan ialah faktor internal (pengetahuan dan motivasi) dan faktoreksternal (kemudahan penerapan teknologi, mengakses informasi teknologi,mengakses sarana produksi, dan prasarana produksi).

- Laki-Laki $\quad$ Perempuan
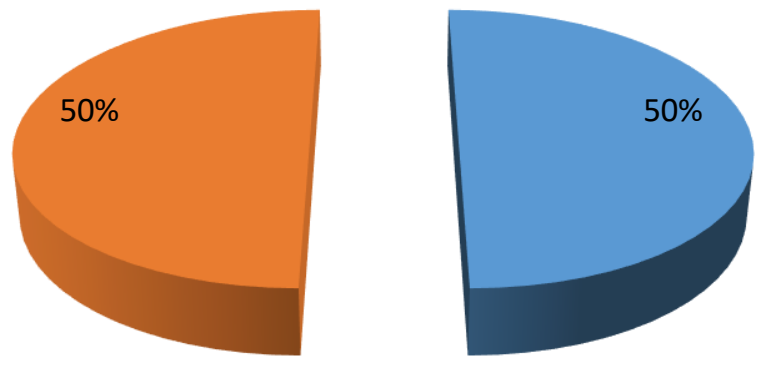

Gambar 2 Jenis kelamin

Tingkat pendidikan yang dimiliki oleh responden mayoritas ialah sekolah dasar degan nilai persentase sebesar $43 \%$. Sementara tidak terdapat satupun responden yang memiliki jenjang pendidikan sarjana. Rendahnya tingkat pendidikan petani menjadi salah satu proble yang harus dipikirkan. Karena adopsi inovasi hazton akan lebih maksimal 
ISSN : 2621-3974 (online)

Volume: 02 Number : 02 (2019)

ISSN : 2622-6154 (print)

apabila tingkatpendidikan petani jauh lebih tinggi denga keterampilan mereka dalam melakukan budiaya padi. Tingkat pendidikan sangat berpengaruh terhadap kemampuan menyerap teknologi inovasi (Burhansyah, 2014).

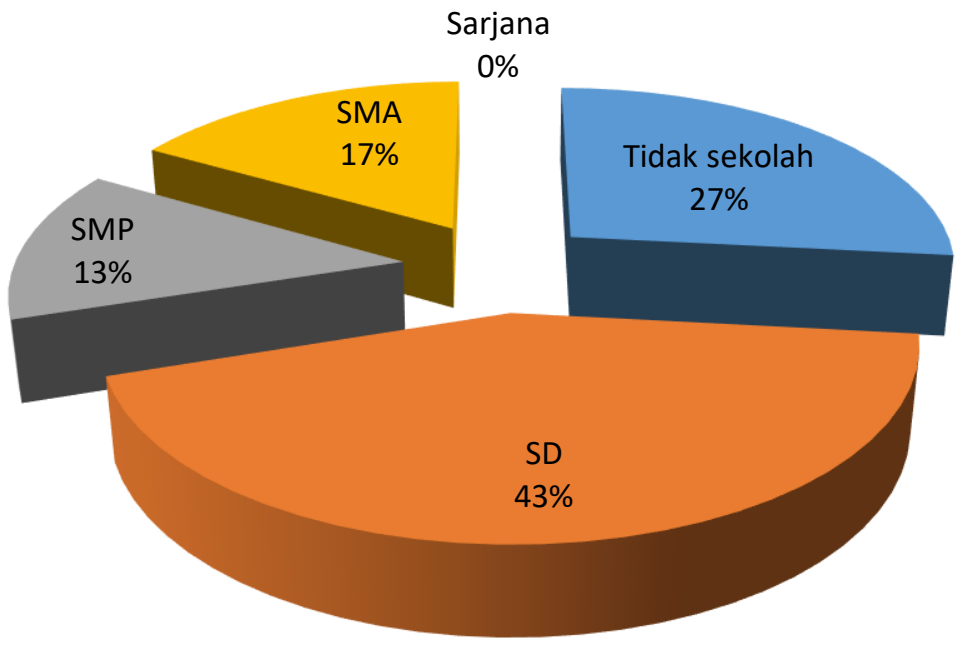

Gambar 3 Tingkat Pendidikan

\section{Pengaruh Kelembagaan, Pembiayaan, dan Kemandirian terhadap Kewirausahaan Petani Padi metode Hazton}

\section{Pengujian Parameter Regresi}

a. Model Fitting Information (Uji Keberartian Model)

Pada tahap ini menjelaskan mengenai masuknya variabel independen ke model final. Hal tersebut menyebabkan naik/turunnya nilai final model. Kondisi tersebut menghasilkan Chi-Square yang signifikan lebih kurang dari nilainya atau model yang layak digunakan. Berdasarkan hasil dari tabel 1, diperoleh nilai ChiSquare sebesar 60,091 dengan nilai signifikasi 0,000. Hal tersebut menunjukkan bahwa model tersebut layak untuk digunakan.

Tabel 1 Model Fitting Information

\begin{tabular}{|l|r|r|r|r|}
\hline Model & \multicolumn{1}{|c|}{$\begin{array}{c}\text {-2 Log } \\
\text { Likelihood }\end{array}$} & Chi-Square & df & Sig. \\
\hline Intercept Only & 126,205 & & & \\
Final & 66,114 & 60,091 & 22 &, 000 \\
\hline
\end{tabular}

Link function: Logit.

b. Goodness of Fit (Uji Kebaikan Model) 
Goodness of Fit menunjukkan uji kesesuaian model model dengan data dimana signifikan harus lebih besar dari nilai alfa. Hal tersebut menunjukkan model sesuai dengan data empiris atau model layak untuk digunakan kembali. Berdasarkan hasil uji pada tabel 2 diperoleh bahwa model memiliki nilai signifikasi sebesar 0,000 menunjukkan bahwa model layak untuk digunakan.

Tabel 2 Goodness-of-Fit

\begin{tabular}{|l|r|r|r|}
\hline & Chi-Square & \multicolumn{1}{|c|}{ Df } & \multicolumn{1}{c|}{ Sig. } \\
\hline Pearson & 1174,824 & 212 &, 000 \\
\hline
\end{tabular}

Link function: Logit.

c. Koefisien Determinasi Model

Koefisien determinasi menunjukkan kemampuan variabel bebas mampu menjelaskan variabel terikat. Berdasarkan hasil uji pada tabel 3, didapatkan bahwa koefisien determinasi Nagelkerke bernilai 0,877 . Hal ini menunjukkan bahwa keseluruhan variabel independen dapat memengaruhi variabel dependen sebesar $87,7 \%$ sedangkan $12,3 \%$ lagi dipengaruhi olehvariabel lain diluar model.

Tabel 3 Pseudo R-Square

\begin{tabular}{|l|r|}
\hline Cox and Snell &, 865 \\
Nagelkerke &, 877 \\
McFadden &, 463 \\
\hline
\end{tabular}

Link function: Logit.

d. Hasil Uji Hipotesis Parsial (Uji Wald dan odds ratio) Tabel 4 Parameter Estimates

\begin{tabular}{|c|c|c|c|c|c|c|c|c|}
\hline & \multirow[t]{2}{*}{ Estimate } & \multirow[t]{2}{*}{ Std. Error } & \multirow[t]{2}{*}{ Wald } & \multirow[t]{2}{*}{ Df } & \multirow[t]{2}{*}{ Sig. } & \multicolumn{2}{|c|}{$\begin{array}{l}\text { 95\% Confidence } \\
\text { Interval }\end{array}$} \\
\hline & & & & & & & $\begin{array}{l}\text { Lower } \\
\text { Bound }\end{array}$ & $\begin{array}{l}\text { Upper } \\
\text { Bound }\end{array}$ \\
\hline \multirow{9}{*}{ Threshold } & {$[\mathrm{Y}=3,17]$} & $-27,718$ & 7,431 & 13,913 & 1 & 0 & $-42,282$ & $-13,153$ \\
\hline & {$[\mathrm{Y}=3,25]$} & $-23,782$ & 6,782 & 12,298 & 1 & 0 & $-37,073$ & $-10,49$ \\
\hline & {$[Y=3,33]$} & $-20,451$ & 6,305 & 10,519 & 1 & 0,001 & $-32,809$ & $-8,092$ \\
\hline & {$[Y=3,42]$} & $-18,211$ & 6,124 & 8,842 & 1 & 0,003 & $-30,214$ & $-6,208$ \\
\hline & {$[\mathrm{Y}=3,50]$} & $-14,586$ & 5,392 & 7,318 & 1 & 0,007 & $-25,154$ & $-4,019$ \\
\hline & {$[\mathrm{Y}=3,67]$} & $-14,064$ & 5,35 & 6,909 & 1 & 0,009 & $-24,55$ & $-3,577$ \\
\hline & {$[\mathrm{Y}=3,75]$} & $-13,572$ & 5,318 & 6,513 & 1 & 0,011 & $-23,996$ & $-3,149$ \\
\hline & {$[\mathrm{Y}=3,83]$} & $-12,633$ & 5,269 & 5,748 & 1 & 0,017 & $-22,961$ & $-2,305$ \\
\hline & {$[\mathrm{Y}=3,92]$} & $-11,544$ & 5,241 & 4,851 & 1 & 0,028 & $-21,816$ & $-1,272$ \\
\hline \multirow{3}{*}{ Location } & Kelembagaan & 0,864 & 2,253 & 9,286 & 1 & 0,002 & $-11,28$ & $-2,449$ \\
\hline & Pembiayaan & 0,617 & 7,337 & 8,681 & 1 & 0,003 & $-35,997$ & $-7,237$ \\
\hline & Kemandirian & 0,987 & 4,761 & 9,911 & 1 & 0,002 & $-24,318$ & $-5,657$ \\
\hline
\end{tabular}

Link function: Logit.

a. This parameter is set to zero because it is redundant 
ISSN : 2622-6154 (print)

Berdasarkan hasil uji hipotesis parsial pada tabel 4 diperoleh bahwa kelembagaan, pembiayaan dan kemandirian berpengaruh signifikan terhadap kewirausahaan. Nilai signifikasi berturut-turut yaitu 0,$002 ; 0,003$; dan 0,002 .

Nilai odds ratio kelembagaan sebesar 2,73 berarti bahwa kewirausahaan sangat ditentukan olah kondisi kelembagaan sebesar 2,73 kali. Nilai odds ratio pembiayaan sebesar 1,85 berarti bahwa kewirausahaan sangat ditentukan oleh kondisi kelembagaan sebesr 1,85 kali. Nilai odds ratio kemandirian sebesar 2,68 berarti bahwa kewirausahaan sangat ditentukan olah kondisi kemandirian sebesr 2,68 kali.

\section{Pengaruh Kelembagaan terhadap Kewirausahaan Petani Padi metode Hazton}

Kelembagaan di pedesaan khususnya desa yang masih memiliki pertanian erat hubungannya dengan kelompok tani atau gabungan kelompok tani. Berdasarkan hasil penelitian, kelembagaan berpengaruh terhadap kewirausahaan petani dalam mengusahakan padi metode Hazton. Nilai odds ratio kelembagaan sebesar 2,73 berarti bahwa kewirausahaan sangat ditentukan olah kondisi kelembagaan sebesr 2,73 kali. Melalui kelembagaan petani dapat mengakses input, melakukan kegiatan pemasaran, berkumpul dan sharing informasi dengan petani lainnya, akses bantuan atau hibah, akses pelatihan dan pembinaan, serta melakukan kegiatan simpan pinjam untuk memperkuat usaha yang dijalankan. Sehingga kelembagaan dinyatakan sangat berpengaruh kepada kewirausahaan petani padi Hazton di Kalimantan Barat. Sampai saat ini kinerja kelembagaan yang baik akan menunjang usahatani yang baik pula (Tedjaningrum\&Nuryaman, 2018). Apabila peran tersebut belum optimal maka pengembangan agribisnis komoditas akan terhambat (Tedjaningsih dan Nuryaman, 2018).

\section{Pengaruh Pembiayaan terhadap Kewirausahaan Petani Padi metode Hazton}

Modal usahatani pada sebagian besar petani merupakanmasalah, maka bantuan kredit dengan bunga rendah sangat diperlukan oleh petani. Pada umumnya petani meminjam uang tujuan utamanya adalah untukmodal usaha tani, walaupun kadangkadang langsung meminjam bentuk saprodi (Purwanti \& Sejati, 2014). Menurut Ridha (2017) kemudahan akan akses pembiayaan dapat meningkatkan intensi kewirausahaan petani. Sehingga akses akan pembiayaan sangat diperlukan. Keberhasilan usahatani yang dilaksanakan tidak akan terlepas dari peran kelembagaanagribisnis.

Berdasarkan hasil analisis didapatkan akses pembiayaan pertanian memilik pengaruh signifikan terhadap kewirausahaan petani. Nilai odds ratio pembiayaan sebesar 1,85 berarti bahwa kewirausahaan sangat ditentukan oleh kondisi kelembagaan sebesar 1,85 kali. Hal tersebut menunjukkan bahwa usahatani padi Hazton sangat membutuhkan pembiayaan pertanian.

\section{Pengaruh Kemandirian terhadap Kewirausahaan Petani Padi metode Hazton}

Kelembagaan, pembiayaan dan kemandirian berpengaruh signifikan terhadap kewirausahaan. Nilai signifikasi berturut-turut yaitu 0,002;0,003; dan 0,002. Nilai odds ratio kelembagaan sebesar 2,73 berarti bahwa kewirausahaan sangat ditentukan oleh kondisi kelembagaan sebesar 2,73 kali. Nilai odds ratio pembiayaan sebesar 1,85 berarti bahwa kewirausahaan sangat ditentukan oleh kondisi kelembagaan sebesr 1,85 kali. Nilai odds ratio kemandirian sebesar 2,68 berarti bahwa kewirausahaan sangat ditentukan olah kondisi kemandirian sebesar 2,68 kali. Menurut Darmayanti (2014), kemandirian dapat meningkatkan minat berwirausaha. Kemandirian untuk tidak bergantung dengan orang lain atau pun pemerintah menjadi poin penting dalam berwirausaha. 


\section{KESIMPULAN}

Kelembagaan, pembiayaan dan kemandirian berpengaruh signifikan terhadap kewirausahaan. Kinerja kelembagaan yang baik akan menunjang usahatani yang baik pula. Usahatani padi Hazton sangat membutuhkan pembiayaan pertanian untuk menyokong kebutuhan modal. Kemandirian untuk tidak bergantung dengan orang lain atau pun pemerintah menjadi poin penting dalam berwirasuha

\section{DAFTAR PUSTAKA}

Abdulrachman et al. 2015. Panduan Teknologi Budidaya Hazton pada Tanaman Padi. Jakarta: Balitbang Kementan

Burhansyah, B. 2014. Faktor-Faktor Yang Mempengaruhi Adopsi Inovasi Pertanian Pada Gapoktan Puap Dan Non Puap Di Kalimantan Barat (Studi Kasus: Kabupaten Pontianak Dan Landak). Informatika Pertanian. 23(1): 65-74

Darmaji. 2012.Analisis Kewirausahaan Petani. AGRIKA 6(1): 49-64

Darmayanti, R. 2014. Hubungan KemandirianDengan Minat Berwirausaha Iluni Prodi D3 JurusanKesejahteraan Keluarga Fakultas TeknikUniversitas Negeri PadangUniversitas Negeri Padang: Fakultas Teknik

Endang, R, P., Tenaya I, M, N., Astiti, N, W, S. 2014. Peran Wanita Tani dalam Penerapan Teknologi Pengelolaan Tanaman Terpadu (PTT) pada Usahatani Jagung di Kecamatan Pringgabaya Kabupaten Lombok Timur. Jurnal Manajemen Agribisnis. 2(1): 76-83

Ningrum, N, W, \& Effendy. 2016. Analisisi Pendapatan dan Kelayakan Usahatani Padi Sawah di Desa Laantula Jaya Kecamatan Witaponda Kabupaten Motowali. Agroteknis4(3): 350-355

Noviansyah, Y, \&Bariyah, N. 2018. Analisisi Usahatani Padi Teknologi Hazton di Provinsi Kalimantan Barat(Studi Kasus Desa Paniraman, Kecamatan Sugai Pinyuh, Kabupate Menpawah). Jural ekonomi Bisnis da Kewirausahaan. 7(1): $1-19$

Purwanti, T, B.,Sejati, W, K. 2014. Peran Kelembagaan Agribisnis Penunjang Dalam Usaha Tani Padi. Jakarta: PSE Litbang Pertanian

Rahmawati, N,. Triyono,. Sriyadi. 2015. Motivasi Kewirsausahaan Petani Padi Organik di Kabupaten Bantul. SEPA. 12(1): 19-28

Ridha, R, N. Entrepreneurship intention in agricultural sector of young generation in Indonesia. APJIE. 11(1): 76-89

Tedjaningsih, T., Suyudi, Nuryaman, H. 2018. Peran Kelembagaan Dalam Pengembangan Agribisnis Mendong. Mimbar Agribisnis. 4(2): 210-226

Wangke, W, M \& Suzana, B, O, L. 2016. Adopsi Petani Terhadap Inovasi Tanaman Padi Sawah Organik Di Desa Molompar Kecamatan Tombatu Timur, Kabupaten Minahasa Tenggara. Agri-SosioEkonomi Unsrat. 12(2): 143-152

Wibowo, R \& Subiyono. 2005. Agribisnis Tebu Membukan Ruang Masa Depan Industri Berbasis Tebu Jawa Timur. Jakarta: Perhepi 